\title{
ANALGETICACTIVITY TEST OF ETHANOL EXTRACT OFTAMARIND LEAVES (TamarindusIndica L.) TO MALEMICE OF SWISS STRAIN
}

\author{
Sri SaptutiWahyuningsih ${ }^{1}$, Fami Pratiwi ${ }^{2}$, Anom Parmadi ${ }^{3}$ \\ ${ }^{1}$ Pharmaceutical Diploma 3 Study ProgramSchool of Health Polytechnics Bhakti Mulia \\ ${ }^{2}$ Pharmaceutical Diploma 3 Study ProgramSchool of Health Polytechnics Bhakti Mulia \\ 3Pharmaceutical Diploma 3 Study ProgramSchool of Health Polytechnics Bhakti Mulia \\ Corresponding author :saptutiwahyu@gmail.com
}

\begin{abstract}
Tamarind is a medicinal plant that has benefits as an antiseptic, antipyretic and analgetic (anti-pain). Pain is an unpleasant sensory and emotional experience due to actual or potential damage.The purpose thisstudy to determine the optimal analgetic and dosage activity of tamarind leaf ethanol extract on male mice swiss strain induced by acetic acid. The method used is analysis of results by observing the amount of stretching of mice every five minutes for an hour. The cumulative amount of stretching in mice to calculate the analgetic activity was obtained from the amount of stretching of mice induced by acetid acid intraperitoneally within 30 minutes after orally induced. Statistical analgetic data using kolmogorov-smirnov normality test, test of homogenity of variances followed by Anova test and post hoc tests using SPSS 24.0 for windows. Percentanalgesic activity of ethanol extract of leaves tamarind dosage $5 \%, 10 \%, 20 \%$ wererespectively $(9,81$ $\pm 2,24) \%,(24,68 \pm 2,10) \%$ and $(36,39 \pm 3,06) \%$. Ethanol extract of leaves tamarind dosage $20 \%$ provide the most optimal activity analgesic
\end{abstract}

Keywords: tamarind leaves, analgesic

\section{Intoduction}

Tamarind leaves (Tamarindusindica L.) can be used as a cure for fever (antipyretics), pain relievers (analgetic) and antiseptics (Dalimartha, 2006). In previous studies it was stated that the infusion of AsamJawa (Tamarindusindica L.) leaf could be used as an analgetic. Because of the content of flavonoids, the mechanism of flavonoids as an analgetic can inhibit the formation of prostaglandins so as to reduce pain (Sariana, 2011). Pain is an unpleasant sensory and emotional experience due to actual or potential tissue damage. Pain occurs with many disease processes or together with several diagnostic or treatment examinations (Smeltzer, 2001). Utilization of tamarind leaves is expected to increase productivity value added from tamarind tree (Tamarindusindica L.)

\section{Methods}

Tool

Analytical scales (Satorius), Waterbath (Local), Blenders (Miyako), oral syringes (Terumo), injection syringes (Terumo), stopwatches.

Material

Glacial Acetic Acid, Acetosal, 70\% ethanol, Tamarind Leaves harvested from Nguter Sukoharjo area, Coconut oil and Swiss male mice. 
Stages of Research

\section{Disappearance Phase}

The extraction used a maceration method, with $2000 \mathrm{ml}$ of $70 \%$ ethanol and 400 grams of Asam Jawa leaves powder (1: 5). then soaked and covered with plastic. Left for two days protected from the sun, while being stirred repeatedly, after two days, the juice is mixed with a flannel cloth into a glass becker, then the juice is evaporated on the waterbath until all ethanol evaporates.

\section{Testing Phase}

a. Mice are divided into five groups, each consisting of five mice that were previously fasted for 18-24 hours while still being given a drink.

b. The negative control group I was given coconut oil (25 ml / kg BW). Group II positive control was given Acetosal (65 mg / kg BW). Group III EEDAJ 20\%. Group IV EEDAJ 10\%. EEDAJ Group V 5\%.

c. Providing test preparation for each group orally,

d. 30 minutes later the test animals were given acetic acid solution $(100 \mathrm{mg} / \mathrm{kg}$ BW) intra-peritoneally.

e. After that, it was observed and calculated the cumulative number of stretching mice every 5 minutes for 1 hour.

f. Pain is characterized by the appearance of abdominal cramps and legs pulled back.

g. The analgesic effect test with stretching method is determined by calculating the cumulative amount for 60 minutes

Stages of Research

1. Disappearance Phase

The extraction used a maceration method, with $2000 \mathrm{ml}$ of $70 \%$ ethanol and 400 grams of Asam Jawa leaves powder (1: 5). then soaked and covered with plastic. Left for two days protected from the sun, while being stirred repeatedly, after two days, the juice is mixed with a flannel cloth into a glass becker, then the juice is evaporated on the waterbath until all ethanol evaporates.

2. Testing Phase a. Mice are divided into five groups, each consisting of five mice that were previously fasted for 18-24 hours while still being given a drink.

b. The negative control group I was given coconut oil (25 ml / kg BW). Group II positive control was given Acetosal (65 mg / kg BW). Group III EEDAJ $20 \%$. Group IV EEDAJ 10\%. EEDAJ Group V 5\%.

c. Providing test preparation for each group orally,

d. 30 minutes later the test animals were given acetic acid solution $(100 \mathrm{mg} / \mathrm{kg}$ $\mathrm{BW}$ ) intra-peritoneally.

e. After that, it was observed and calculated the cumulative number of stretching mice every 5 minute interval for 1 hour.

f. Pain is characterized by the appearance of abdominal cramps and legs pulled back.

g. The analgetic effect test with stretching method is determined by calculating the cumulative amount for 60 minutes

\section{Data Analysis}

The research data in the form of the amount of stretching in each treatment group then calculated the analgetic activity which was expressed as $\%$ analgetic activity (\% DA) with the following formula:

$=(\Sigma$ stretching $\mathrm{k}(-)-$ at stretching test $) /\left(\sum\right.$ stretching $\left.\mathrm{k}(-)\right) \times 100 \%$

Information:

At stretching negative control = number of stretching negative controls

At stretching test $=$ the amount of stretching of the test material

\section{Results and Discussion}

\section{Maseration results}

The results of maceration in the form of thick extract as much as $52.94 \mathrm{~g}$ with a yield of $13.23 \% \mathrm{~b} / \mathrm{b}$.

2. Analgetic Activity Test Results

Variations in extract dosage used are doses of $5 \%, 10 \%$ and $20 \%$. 
Percentage of analgeticactivity from the variation of the extract dose will be compared with the percent of the analgeticactivity of the positive control, namely Acetosal with a dose of $65 \mathrm{mg} /$ $\mathrm{kg} \mathrm{BW}$ of mice and solvent control, namely coconut oil with a dose of $25 \mathrm{ml} /$ $\mathrm{kg}$ BB. Observations were made based on the amount of stretching which is a pain reaction shown by the test animal, the observation was carried out for 1 hour with an interval of observation every 5 minutes.

This study uses Tamarind leaves (Tamarindusindica L.) as a test material, because the leaves of AsamJawa have chemical substances that can work to inhibit prostaglandin biosynthesis or pain mediators. Analgetic tests were carried out because there were not many people who knew that AsamJawa leaves had efficacy as an analgetic. Analgetic is a drug used to reduce or eliminate pain or pain relief medications without eliminating awareness.

The method of extraction used is maceration with $70 \%$ solvent, because almost all the compounds in the plant are soluble in ethanol $70 \%-80 \%$ (Fong et al, 1978). $70 \%$ ethanol is very effective in producing optimal amounts of active ingredients, where impurity is only on a small scale participating in the extracting liquid (Voight, 1995), besides that $70 \%$ Ethanol can easily enter the cell membrane of plant material and has lower toxicity compared with methanol (Tiwari et al, 2011).

Table 1. Effect of Test Preparations on Acetat Acid-Induced Mice Stretching

\begin{tabular}{|c|c|c|c|c|c|}
\hline Treatment & No & $\begin{array}{c}\text { Amount } \\
\text { of } \\
\text { Stretching }\end{array}$ & $\underset{(\%)}{\operatorname{Mean} \pm \text { SEM }}$ & $\begin{array}{c}\text { Analgesic } \\
\text { Activity } \\
(\%)\end{array}$ & Mean \pm SEM $(\%)$ \\
\hline \multirow{5}{*}{$\begin{array}{c}\text { Coconut Oil } \\
\text { Dose } 25 \\
\mathrm{ml} / \mathrm{kg} \mathrm{BB}\end{array}$} & I & 61 & \multirow{5}{*}{$63,2 \pm 0,74$} & \multirow{5}{*}{0} & \multirow{5}{*}{0} \\
\hline & II & 58 & & & \\
\hline & III & 64 & & & \\
\hline & IV & 67 & & & \\
\hline & $\mathrm{V}$ & 66 & & & \\
\hline \multirow{5}{*}{$\begin{array}{c}\text { Acetosal } \\
\text { Doe } \\
65 \mathrm{mg} / \mathrm{kg} \text { BB }\end{array}$} & I & 31 & \multirow{5}{*}{$37 \pm 0,44$} & 50,95 & \multirow{5}{*}{$41,46 \pm 2,60$} \\
\hline & II & 38 & & 39,87 & \\
\hline & III & 37 & & 41,46 & \\
\hline & IV & 38 & & 39,87 & \\
\hline & $\mathrm{V}$ & 41 & & 35,13 & \\
\hline \multirow{5}{*}{$\begin{array}{c}\text { Ethanol } \\
\text { Extract of } \\
\text { Tamarind } \\
\text { Dose Leaves } \\
20 \%\end{array}$} & $\mathrm{I}$ & 43 & \multirow{5}{*}{$40,2 \pm 0,50$} & 31,96 & \multirow{5}{*}{$36,39 \pm 3,06$} \\
\hline & II & 38 & & 39,87 & \\
\hline & III & 35 & & 44,62 & \\
\hline & IV & 46 & & 27,22 & \\
\hline & $\mathrm{V}$ & 39 & & 38,29 & \\
\hline \multirow{5}{*}{$\begin{array}{c}\text { Ethanol } \\
\text { Extract of } \\
\text { Tamarind } \\
\text { Dose Leaves } \\
10 \% \\
\end{array}$} & I & 49 & \multirow{5}{*}{$47,6 \pm 0,59$} & 22,47 & \multirow{5}{*}{$24,68 \pm 2,10$} \\
\hline & II & 51 & & 19,30 & \\
\hline & III & 49 & & 22,47 & \\
\hline & IV & 44 & & 30,38 & \\
\hline & $\mathrm{V}$ & 45 & & 28,80 & \\
\hline \multirow{5}{*}{$\begin{array}{c}\text { Ethanol } \\
\text { Extract of } \\
\text { Tamarind } \\
\text { Dose Leaves } \\
5 \%\end{array}$} & I & 53 & \multirow{5}{*}{$57 \pm 0,51$} & 16,14 & \multirow{5}{*}{$9,81 \pm 2,24$} \\
\hline & II & 57 & & 9,81 & \\
\hline & III & 59 & & 6,65 & \\
\hline & IV & 61 & & 3,48 & \\
\hline & $\mathrm{V}$ & 55 & & 12,97 & \\
\hline
\end{tabular}


Maseration is an extraction which is done by soaking the simplicia powder in the liquid and is the easy and simplest method to do with stirring to speed up the process of extraction. The analgetic method used is a chemical stimulation method, which is induced by acetic acid as a pain stimulator because Acetic Acid causes pain in the tissue so that it can cause stretching in mice as a sign of pain, which is to pull both of its hind legs. Acetic acid that is used is Glacial Acetic Acid, because it has the properties of water soluble, not oxidized and not photosensitized (Parmar and Prakash, 2006).

This study uses mice test animals, because the induction of intraperitoneal chemicals in mice will cause irritation to the stomach and result in stretching effects (Parmar and Prakash, 2006). Mice also have genes that are similar to humans, have the ability to breed high. In addition, handling for mice is easy, because the small form that causes the drug used is relatively quickly manifested. Mice used are male mice, because they have a stable biological condition than female mice, because they are affected by the esterus cycle or reproductive cycle.

Based on the orientation of acetic acid doses that have been carried out, researchers used acetic acid at a dose of $100 \mathrm{mg} / \mathrm{kg} \mathrm{BB}$. The dosage is used based on the consideration of the number of squirming mice caused by mice after induced acetic acid at a dose of $300 \mathrm{mg} /$ $\mathrm{kg} \quad \mathrm{BB}$ raises too high cumulative stretching. In the orientation of the administration of acetic acid researchers used 30 .

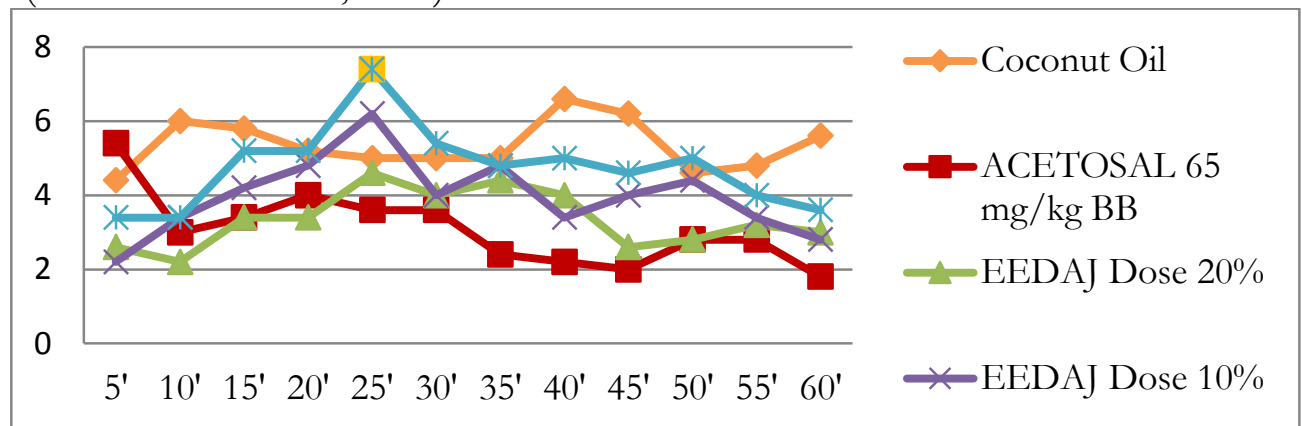

Figure 2. Graph of the relationship between time intervals and acetat-induced mouse stretching of mice

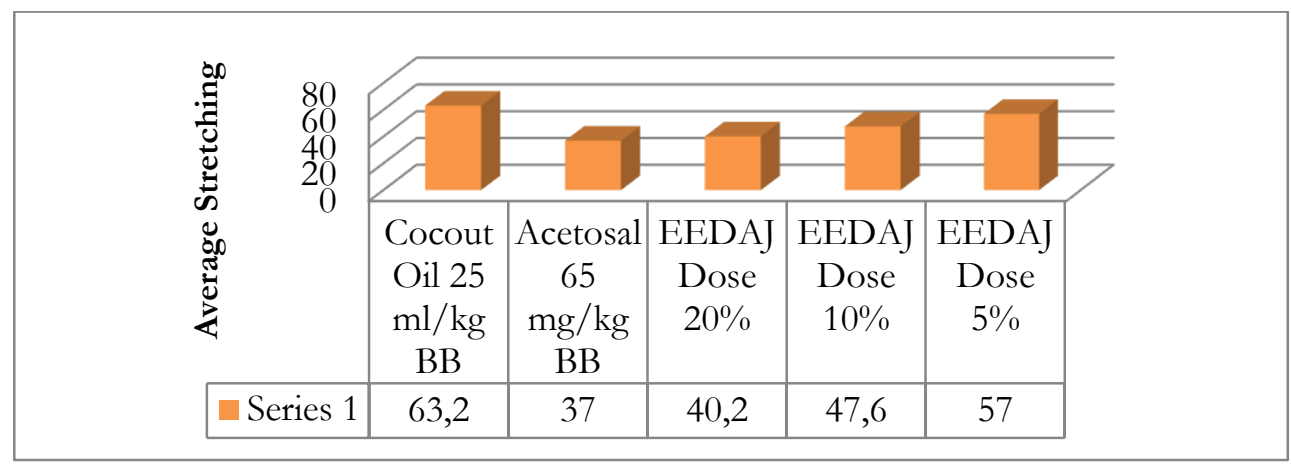

Figure 3. Cumulative Amount Stretching Acetic Acid Induced Mice

Coconut oil has the highest average amount of stretching, because coconut oil does not have analgetic activity, then Acetosal has the least amount of stretching because Acetosal has a strong analgeticactivity. For the ethanol extract of AsamJawa leaves, the smaller the dose, the more stretching is generated and the higher the dose, the less stretching is generated which means that the extract has analgeticactivity. This is because the dose of $20 \%$ can be absorbed in the 
digestive tract more than the dose of $5 \%$ or $10 \%$.

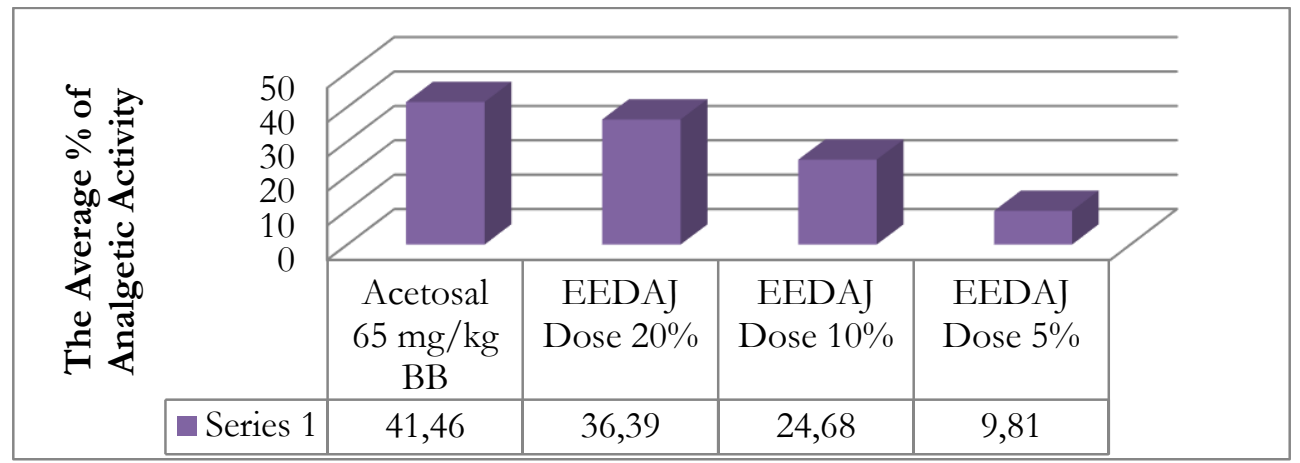

Figure 4. Percentage of the Activity of Test Preparation for Mice Induced by Acetic Acid

It can be seen that the average amount of analgeticactivity for ethanol extract of AsamJawa leaves is $20 \%$ which is close to positive control (Acetosal) compared to doses of $5 \%$ and $10 \%$. This shows that a dose of $20 \%$ has an analgetic effect which is more than the dose of $5 \%$ and $10 \%$. Because at a dose of $20 \%$ contains more active substances than doses of $5 \%$ and $10 \%$ so that it gives more therapeutic effect.

\section{Statistics Test Results}

The results of the data obtained from analgetic testing were then statistically analyzed by ANOVA test to find out whether there was a significant difference in the presence or absence of analgetic from the OnewayAnova test, based on the test results the probability value obtained was $0.000<0.05, \mathrm{H} 0$ was rejected, there was a significant difference between percent of analgeticactivity of ethanol extract of AsamJawa leaves.

\section{Conclusion}

Based on the results of the study, ethanol extract of Asam Jawa leaves had analgetic activity against mice. The dose of Ethanol extract of Asam Jawa leaves (EEDAJ) which has the most optimal analgetic activity is at a dose of $20 \%$ obtaining an average percent of analgetic activity of $(36.39 \pm 3.06) \%$, because it approaches the average percent

\section{References}

Dalimartha, S. 2006. Attas TumbuhanObat Indonesia. Jilid 5. PustakaBunda. Jakarta

Fong HHS, Maung TW and Farnsworth N. 1978. Phytochemical Sreening. New York: Department of Pharmacognosyang Pharmacology, College of Farmasi, University of Illions At The Medical Center

Parmar, N.S dan Prakash, S. 2006. Screening Methods in Pharmacology. Oxford: Apha Science International

Sariana. 2011. Uji Efek Analgetik dari Infusa Daun Asam Jawa Tamarindus Indica Linn) pada Mencit (Mus Musculus). Universitas Islam Negeri Alauddin Makassar

Smeltzer, Suzanne C dan Brenda G. Bare. 2001. KeperawatanMedikalBedah 2. Edisi 8. Jakarta: EGC

Tiwari, P., Kumar, B., M., G dan Kaur, H. 2011. Phytochemical Screening and Extraction: a Review. International Pharmaceutical Science

Voight, R. 1995. Buku Pelajaran Teknologi Farmasi. Diterjemahkan oleh Soendani N.S. Yogyakarta: UGM Press 